This is a preprint; for the publisher's typeset version, please go to Taylor \& Francis:

http://www.tandfonline.com/toc/htip20/54/2\#.Vb933PIViko

Wohlwend, K. E. (2015). One screen, many fingers: Young children's collaborative literacy play with digital puppetry apps and touchscreen technologies.

Digital media and literacies special issue. Theory Into Practice, 54, 154-162.

\title{
One Screen, Many Fingers: \\ Young Children's Collaborative Literacy Play with Digital Puppetry Apps and Touchscreen Technologies
}

Karen E. Wohlwend

2015

\section{Theory into Practice}

Digital Media and Literacies special issue

Issue Editors:

James Paul Gee

Nicholas E. Husbye

Jennifer Connor-Zachocki 
What is collaborative literacy play with digital puppetry apps and touchscreen technologies? And what does it really look like in classrooms? Let's begin with an illustration:

Three girls huddle around an iPad tablet on the library table in the kindergarten classroom, giggling, making sound effects, and occasionally squealing in surprise as their fingers pinch, squeeze, and slide across the tablet's glass surface to animate the cartoon characters that are scattered around the touchscreen.

At first glance, the children's play with a digital puppetry app looks crowded, noisy, and chaotic- the kind of play that teachers might move quickly to redirect to more orderly turn-taking and quiet composing. However, a closer look at just fifteen seconds of continuous activity is enough to reveal the collaborative literacy play - coordinated storying, digital literacy learning, multimodal production, and play negotiation--that is actually happening here. What makes this vignette even more interesting is that it occurs during the first moments of María's first opportunity to play with this particular app. In this app PuppetPals, children can immediately begin animating by pressing the red record button, dragging the cut-out characters on and offstage, moving them around the scene, and voicing their parts. Important to the focus on collaboration in this article, children need additional hands to animate more than one or two characters in order to create more complex stories.

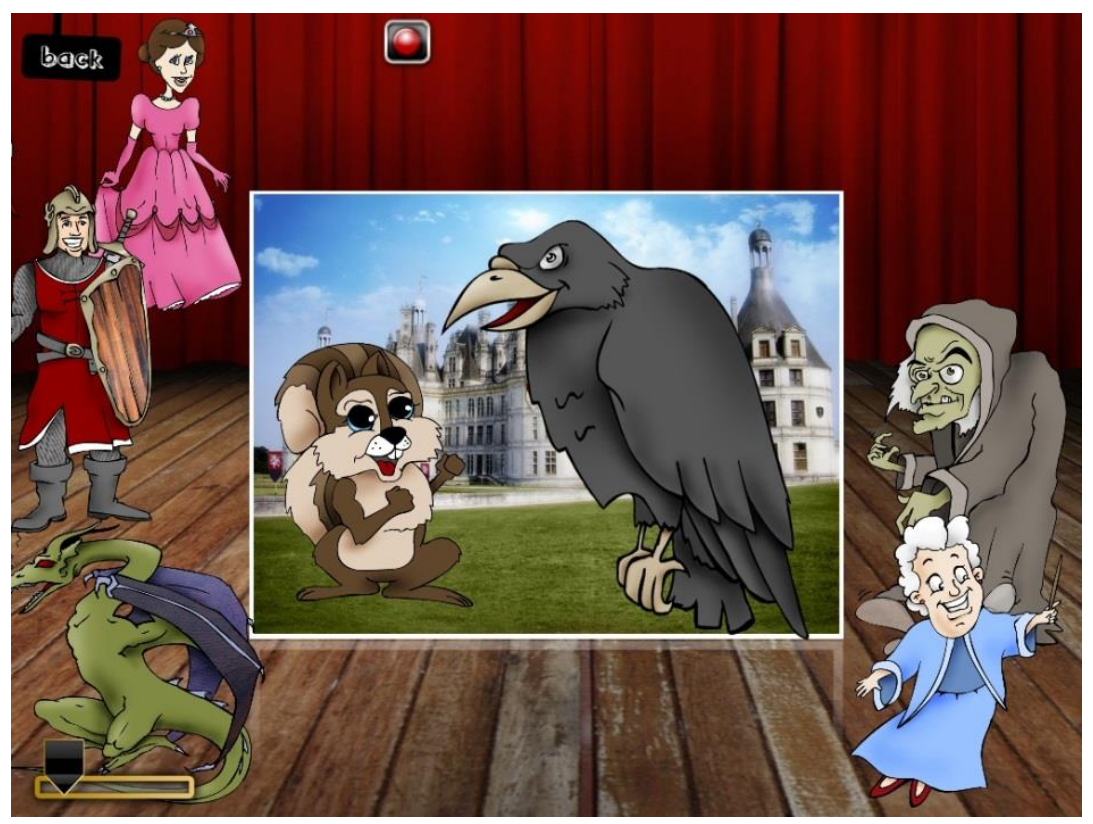

Figure 1. Screen Capture of iPad Touchscreen: Characters on- and off-stage in PuppetPals digital puppetry app 
The transcript below begins almost immediately after María opens the app and selects six characters and a backdrop: a crow, a chipmunk, a prince, a princess, a witch, and a dragon in a castle scene. (See Fig. 1).

María: Aiiigh! I'm going to eat you!

[Enacting Crow by stretching and pinching Crow character with her thumb and forefinger on her right hand to repeatedly make Crow grow and shrink until it fills half the screen].

Get the girl chipmunk out.

[Directing Alma by tapping Chipmunk with her left forefinger, also inviting Alma join her play and to touch the screen. She establishes herself as the director with this move.]

Alma: Eek. Eek. Eek.

[Responding to María's direction; Enacting Chipmunk. In one circling motion, drags Chipmunk from top left of scene to the off-stage margin, and then drags Chipmunk back on-stage at bottom left of the castle scene. She establishes herself as an actor in the story and adds Chipmunk character to the story.]

María: No, get him small.

[Directing Alma; Demonstrating resizing action while using her thumb and forefinger pinch to squeeze Alma's Chipmunk to show resizing action. She tacitly accepts Alma's opposing idea to add Chipmunk character to the scene.]

Alma: [Following direction; Attempting demonstrated action but less effectively: she uses two forefingers on separate hands to resize Chipmunk smaller.]

María: Don't get him any smaller than this.

[Editing Alma's character resizing by placing her thumb and forefinger between María's fingers and stretches Chipmunk to make slightly larger (See Fig. 2).]

A minute later, Kaila who has been watching intently, reaches in and on her first attempt successfully resizes the Chipmunk to fill the screen, prompting discussion and clarification about which characters should be in the scene and what should happen next.

Clearly a lot of clarifying talk and digital composing is going on. But are we recognizing the learning potential in this messy playfulness? Are we teaching for these changing literacies and changing technologies? 


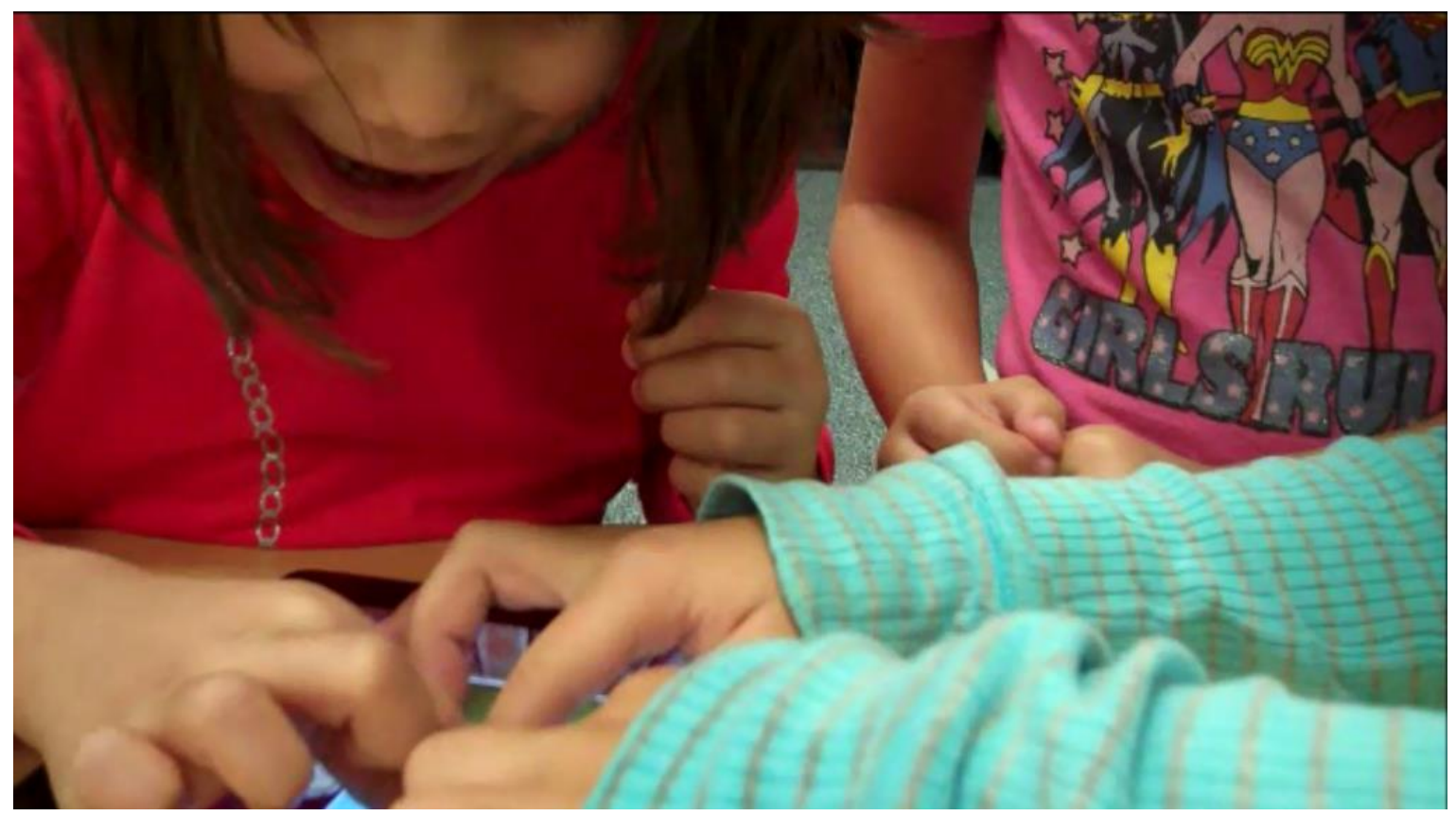

Figure 2. Multiple fingers manipulating characters on iPad Touchscreen in digital puppetry app

\section{Changing Literacies, Changing Technologies}

In the early twenty-first century, definitions of literacy are evolving to include multiple ways of working with variety of screen-based media, including webpages, videos, video games, and apps on mobile devices (Burnett, 2010; Darling-Hammond, et al., 2013). We not only read and write printed words on a page of paper; we now blog, podcast, text message, video-record, photo-edit, and otherwise manage complex combinations of print, sound, image, and animation as we send texts across vast social networks. Our text messages, blog posts, and YouTube clips are not individually-authored manuscripts; rather they are multimedia co-productions shared with an interactive audience who respond, comment, like, post, and retweet to their followers (Knobel $\&$ Wilber, 2009). Even the pithy stories we write in 140-character tweets connect to other larger conversations that build on and echo each other, creating networks of linked texts and shared understandings.

Increasingly, even very young children are reading and writing on screens, often on mobile devices with touchscreens (Neumann \& Neumann, 2013) such as smartphones and tablets. In fact, "children under 12 constitute one of the fastest growing segments of mobile technology users in the U.S." (Shuler, 2009, p. 3). What does this mean for teachers who want to teach children to use the literacies that fill modern childhoods? Are we recognizing and incorporating the literacy practices that are so prevalent in children's worlds? 
In this article, I argue that key digital literacy practices such as collaborative composing are learned easily when young children play together with digital apps on touchscreen devices. Children's collaborative composing with a digital puppetry app on a touchscreen--with many hands all busy dragging, resizing, and animating puppet characters, and many voices making sound effects, narrating, directing, and objecting--appears aimless, chaotic, and in sharp contrast to the orderly matching activities in prevalent letter and word recognition apps that dominate the early childhood educational software market (Guernsey, Levin, Chiong, \& Severns, 2012). The crowded collaboration around a single touchscreen looks messy but produces a complex text built with 1) touches, swipes, and other embodied actions that make up digital literacy practices, 2) sensory or multimodal layers of colorful images, dialogue, sound effects, and movement that make up animated stories; and 3) negotiation and pooling of children's individual story ideas for shared pretense that make up playful collaboration — all contained on a 9.7 inch screen.

\section{Digital Literacies. Animated Stories, and Playful Collaboration}

\section{Finger Swipes and Embodied Actions in Digital Literacy Practices}

Children are learning new ways of using bodies for reading and writing as they use the digital devices that surround them. For example, even toddlers understand that finger taps, pinches, and stretches on touch screens are important new ways of engaging text. The viral video on YouTube "A Magazine is an iPad That Does Not Work" quickly illustrates this (http://www.youtube.com/watch? $\mathrm{v}=\mathrm{aXV}$-yaFmQNk). Here, a toddler uses her fingers to press, tap, swipe, and pinch icons on the screen on an iPad to open various apps. However when she tries using the same finger movements on several magazines, nothing happens. Puzzled, she stops to test her finger by pressing on her own knee. This adorable video shows a toddler's emerging understanding that "turning the page" involves different actions with an iPad than with a magazine. On a touchscreen display, pressing an icon or swiping a finger across the screen changes the image and pinching and spreading thumb and fingers resizes a page. These actions are key abilities in touchscreen reading, a digital literacy practice, which as this baby discovered, simply does not work in the same way with print on a paper page (Wohlwend, 2013).

As children use keypads and touchscreens on a broad range of technological devices, they learn to browse, view, interpret, navigate, interact, and produce original texts (Burnett \& Merchant, 2013). Guy Merchant (2005) suggests that learning to read online texts requires a new kind of literacy knowledge and skills: concepts specific to screen-based text (e.g., keyboard use, the mouse-cursor relationship, screen navigation) require new concepts about screens, awareness of the organization of space and image on screens that extends Marie Clay's (1993) concepts about print needed to handle books (e.g., left to right tracking, return sweep). Table 1 lists a few digital literacy practices with computer technologies, drawn from studies of children's screen literacies and collaborative play in virtual worlds such as Webkinz (Black, 2010; Wohlwend, Vander Zanden, Husbye, \& Kuby, 2011) and Club Penguin (Marsh, 2011; Wohlwend \& Kargin, 2013). For example, in Club Penguin, children combine keyboard and 
mouse taps, cursor moves, finger jabs, and other ways of interacting with computer screens as they play side-by-side and navigated in and out of arcade games, trading posts, igloos on-screen. Now with touchscreens, I argue these practices must be further extended to include concepts beyond print for touchscreens with camera-enabled tablets. Table 2 suggests several additional digital literacy practices for digital devices equipped with touchscreen and voice-recognition capabilities such as tablet technologies and icon-based navigation.

Table 1. Actions in Digital Literacy Practices with Computer Technologies

\begin{tabular}{|l|l|l|}
\hline $\begin{array}{l}\text { Computer } \\
\text { Technologies }\end{array}$ & Action & Sample Digital Literacy Practices \\
\hline Mouse & Double-Clicking & $\begin{array}{l}\text { Select and open part of a digital text (e.g, webpage, e- } \\
\text { book, video game, window) }\end{array}$ \\
\cline { 2 - 3 } & Clicking & Select or open a menu of options, or confirm a choice \\
\cline { 2 - 3 } & Hovering & See and read options, information, and menus \\
\cline { 2 - 3 } & Scrolling & Move through text or images across a window \\
\hline Keyboard & Tapping & Confirm choice or print a symbol by pressing keys \\
\cline { 2 - 3 } & Toggling & $\begin{array}{l}\text { Moving repeatedly (e.g., jumping) by quickly } \\
\text { alternating two keys, especially with numeric pad or } \\
\text { arrow keys }\end{array}$ \\
\hline
\end{tabular}

Table 2. Actions in Digital Literacy Practices with Tablet Technologies

\begin{tabular}{|c|c|c|}
\hline $\begin{array}{l}\text { Tablet } \\
\text { Technologies }\end{array}$ & Action & Sample Digital Literacy Practices \\
\hline \multirow[t]{5}{*}{ Touchscreen } & Tapping & $\begin{array}{l}\text { Select and open or turn a page } \\
\text { Enable voice-over or other read-aloud options } \\
\text { Select, highlight, copy, and paste text } \\
\text { Play or animate }\end{array}$ \\
\hline & Swiping & $\begin{array}{l}\text { Scroll through screens } \\
\text { Turn a page } \\
\text { Select and highlight text }\end{array}$ \\
\hline & Pinching & Resize an object, image, or screen to make smaller \\
\hline & Stretching & Resize an object, image, or screen to make larger \\
\hline & Dragging & $\begin{array}{l}\text { Add, delete, move or reposition objects } \\
\text { Draw using a paint program }\end{array}$ \\
\hline Voice & Speaking & $\begin{array}{l}\text { Locate apps or search within a browser app } \\
\text { Open a digital text or application } \\
\text { Add narration and dialogue to a video }\end{array}$ \\
\hline
\end{tabular}




\section{Layering Multimodal Meanings in Animated Stories}

Software applications often position children as readers and viewers, rather than authors and producers of digital media. However, filmmaking and digital puppetry now offer children an opportunity to produce their own animated stories, significantly in ways that encourage collaboration, build upon their play interests, and support their emerging digital literacies. Digital puppetry apps allow children to create stories by dragging cartoon or photo cut-out characters across a backdrop, while narrating or voicing their own dialogue and sound effects. Although such puppet shows can be easily produced in a matter of minutes, these videos are complex products of countless decisions that coordinate character choices such as the relative size of the characters, each player's moves, the shared storylines, dialogue, and so on. In this way, digital video productions are multimodal ensembles (Kress, 2009; Winters, 2009), with story meanings deepened by the layered meanings represented simultaneously through speech, image, action, music, and sound effects (Flewitt, 2013; Siegel, 2006).

Furthermore, this complexity offers multiple pathways into literacy by giving children a choice of features to notice and a wide array of sensory modes to explore (e.g., sound, visual, movement, speech, and haptic modes [Simpson, Walsh, \& Rowsell, 2013]). In digital puppetry, this means that children can contribute to the story in many ways: by drawing and coloring puppets, props, or background scenes, by taking photos of classroom toys for cut-out characters, by manipulating and moving characters and props, by creating voiceover dialogue and narrations, by selecting and layering on music and sound effects, and so on (Wohlwend, Buchholz, Wessel Powell, Coggin, \& Husbye, 2013).

\section{Mixing Ideas in Playful Collaboration}

Play is a collaborative literacy that uses bodies and artifacts, such as dolls and action figures, for creating and coordinating a shared storyline among multiple players (Wohlwend, 2011). Of course for decades early childhood educators have known that during play young children are making stories together as they play (Dyson, 2013; Paley, 2004). Whether playing house or playing video games, all players contribute to the emerging story and must work together not only to create an unfolding script of what happens next and who does what but also to maintain the pretend space. This is not to say that children's individual ideas always fit together neatly.

During play, stories are openly under construction as children propose characters or story action, disagree, negotiate, and improvise solutions as they work through differing visions of who-should-play-whom and what-should-happen-next in a co-played text. Ethnographic studies of preschool play show that young children can manage this complexity by stepping in and out of pretense to negotiate (Corsaro, 2003) and improvise (Sawyer, 1997) to keep the play going. Vygotsky (1935/1978) theorized that this kind of imaginative pretense is an action-oriented precursor of paper and pencil writing. As children pretend, they give new symbolic meanings to 
real materials, similar to the ways that readers link printed words to symbolized ideas during reading and writing. In my work, I argue that it is time to update this notion to recognize that play is no longer simply a precursor to writing but a literacy in its own right that connects to animation and live-action videos that now make up the new textual landscape (Carrington, 2005).

\section{Imagining Collaborative Pedagogies for Digital Futures}

Today's schoolchildren will be 21 st century citizens who very likely will need to be experts at collaborating and inventing together...with literacies and technologies we cannot yet imagine. Elsewhere (Wohlwend, 2009, 2010), I have argued that we need new early literacy pedagogies that encourage children to play into their future literacies rather than policies that play it safe by shrinking the curriculum to fit the tiny bubbles on standardized tests. Researchers are already conceptualizing collaborative digital literacies (Rowe, 2012) and productive pedagogies (Marsh, 2009) and identifying teaching practices that support children's playful and productive interactions with new technologies (Levy, Yamada-Rice, \& Marsh, 2013; Paciga, Lisy, \& Teale, 2013; Rowe, 2012; Rowsell, Saudelli, Scott, \& Bishop, 2013; Siegel et al., 2008).

To address the possibilities and realities of modern childhoods, we need new basics (Dyson, 2013). This means thinking beyond even our best practice in literacy teaching — such as our familiar reading and writing workshops--and envision a play-enriched and technologyinspired literacy learning that makes sense for today's pixel-saturated 24/7 connected world. In other words, we need to expand reading and writing workshops into vibrant and creative classroom studios or "playshops" (Wohlwend, 2011) with media-rich and play-centered digital literacy curricula where children collaborate to produce animated puppet shows, live action plays, and digital films. Playshops bridge literacy practices, play, and children's multimedia knowledge in classrooms where teachers support children's video explorations and collaborative film projects that engage new kinds of literacies through play and media production (Vasquez \& Felderman, 2012; Wohlwend, Buchholz, Wessel-Powell, Husbye, \& Coggin, 2013). This shift can be dramatic. When film captures previously temporary play scenarios, children can create stories on their terms using the child-friendly technology, media resources, and narratives that they knew best.

Finally, a key to teaching the new basics for collaborative and productive digital literacies is the recognition that even the youngest students already bring much knowledge about current technologies to school and that we need to reframe literacy curricula to build on these strengths. We can start by building on children's existing digital literacy abilities, pervasive mobile technologies, and collaborative play skills as appropriate and powerful resources for engaged learning in the early childhood classroom. 


\section{References}

Black, R. W. (2010). The language of Webkinz: Early childhood literacy in an online virtual world. Digital Culture \& Education, 2(1), 7-24.

Burnett, C. (2010). Technology and literacy in early childhood educational settings: A review of research. Journal of Early Childhood Literacy, 10(3), 247-270.

Burnett, C., \& Merchant, G. (2013). Learning literacies and new technologies: The current context and future possibilities. In J. Larson \& J. Marsh (Eds.), The Sage handbook of early childhood literacy (2nd ed., pp. 575-586). Los Angeles: Sage.

Carrington, V. (2005). New textual landscapes, information, and early literacy. In J. Marsh (Ed.), Popular culture, new media and digital literacy in early childhood (pp. 13-27). New York: RoutledgeFalmer.

Clay, M. (1993). An observation survey of early literacy achievement. Auckland, NZ: Heinemann.

Corsaro, W. A. (2003). We're friends right? Inside kids' culture. Washington, DC: Joseph Henry Press.

Darling-Hammond, L., Levine, M. H., Barron, B., Bofferding, L., Cayton-Hodges, G., \& Copple, C. (2011). Take a giant step: A blueprint for teaching young children in a digital age. New York: Joan Ganz Cooney Center \& Stanford University.

Dyson, A. H. (2013). Rewriting the basics: Literacy learning in children's cultures. New York: Teachers College Press.

Flewitt, R. (2013). Multimodal perspectives on early childhood literacies. In J. Larson \& J. Marsh (Eds.), The Sage handbook of early childhood literacy (pp. 295-310). Los Angeles: Sage.

Guernsey, L., Levine, M., Chiong, C., \& Severns, M. (2012). Pioneering literacy: In the digital wild west: Empowering parents and educators. New York: New America Foundation \& Joan Ganz Cooney Center.

Knobel, M., \& Wilber, D. J. (2009). Let's talk 2.0: Whether it's Web 2.0 or literacy 2.0, it's a whole new way of thinking. Educational Leadership, 66(6), 20-24.

Kress, G. (2009). Multimodality: A social semiotic approach to contemporary communication. London: Routledge.

Levy, R., Yamada-Rice, D., \& Marsh, J. (2013). Digital literacies in the primary classroom. In K. Hall, T. Cremin, B. Comber \& L. C. Moll (Eds.), International handbook of research on children's literacy, learning, and culture (pp. 333-343). Oxford, UK: John Wiley \& Sons.

Marsh, J. (2009). Productive pedagogies: Play, creativity, and digital cultures in the classroom. In R. Willett, M. Robinson \& J. Marsh (Eds.), Play, creativity, and digital cultures (pp. 200-218). New York: Routledge.

Marsh, J. (2011). Young children's literacy practices in a virtual world: Establishing an online interaction order. Reading Research Quarterly, 46(2), 101-118. 
Merchant, G. (2005). Barbie meets Bob the Builder at the workstation: Learning to write on screen. In J. Marsh (Ed.), Popular culture, new media and digital literacy in early childhood (pp. 183-200). New York: RoutledgeFalmer.

Neumann, M. M., \& Neumann, D. L. (2013). Touch screen tablets and emergent literacy. Early Childhood Education Journal, Online first.

Paciga, K. A., Lisy, J. G., \& Teale, W. H. (2013). Better start before kindergarten: Computer technology, interactive media and the education of preschoolers. Asia-Pacific Journal of Research in Early Childhood Education 7(2), 85-104.

Paley, V. G. (2004). A child's work: The importance of fantasy play. Chicago: University of Chicago Press.

Rowe, D. W. (2012, May). Collaborative writing. Paper presented in featured research to practice symposium, D.W. Rowe (chair). Promising practices for emergent writers: Collaborative writing, digital composing, concept mapping, and science journals. The annual meeting of the International Reading Association, Chicago.

Rowsell, J., Saudelli, M. G., Scott, R. M., \& Bishop, A. (2013). iPads as placed resources: Forging community in online and offline spaces. Language Arts, 90(5), 351-360.

Sawyer, R. K. (1997). Pretend play as improvisation: Conversation in the preschool classroom. Norwood, NJ: Erlbaum.

Shuler, C. (2009). Pockets of potential: Using mobile technologies to promote children's learning. New York: The Joan Ganz Cooney Center at Sesame Workshop.

Siegel, M., Kontovourki, S., Schmier, S., \& Enriquez, G. (2008). Literacy in motion: A case study of a shape-shifting kindergartener. Language Arts, 86(2), 89-98.

Siegel, M. (2006). Rereading the signs: Multimodal transformations in the field of literacy research. Language Arts, 84(1), 65-77.

Simpson, A., Walsh, M., \& Rowsell, J. (2013). The digital reading path: researching modes and multidirectionality with iPads. Literacy, Online

Vasquez, V. M., \& Felderman, C. B. (2012). Technology and critical literacy in early childhood. New York: Routledge.

Vygotsky, L. (1935/1978). Mind in society (A. Luria, M. Lopez-Morillas \& M. Cole, Trans.). Cambridge, MA: Harvard University Press.

Winters, K.-L. (2009). Authorship as assemblage: Multimodal literacies of play, literature, and drama. Unpublished doctoral dissertation., University of British Columbia, Vancouver, British Columbia.

Wohlwend, K. E. (2009). Early adopters: Playing new literacies and pretending new technologies in print-centric classrooms. Journal of Early Childhood Literacy, 9(2), 119-143.

Wohlwend, K. E. (2010). A is for avatar: Young children in literacy 2.0 worlds and literacy 1.0 schools. Language Arts, 88(2), 144-152.

Wohlwend, K. E. (2011). Playing their way into literacies: Reading, writing, and belonging in the early childhood classroom. New York: Teachers College Press. 
Wohlwend, K. E. (2013). Mediated discourse analysis: Tracking discourse in action. In M. M. Albers (Ed.), New methods in literacy research. New York: Routledge.

Wohlwend, K. E., Buchholz, B. A., Wessel-Powell, C., Coggin, L. S., \& Husbye, N. E. (2013). Literacy playshop: Playing with new literacies and popular media in the early childhood classroom. New York: Teachers College Press.

Wohlwend, K. E., \& Kargin, T. (2013). "Cause I know how to get friends--plus they like my dancing": (L)earning the nexus of practice in Club Penguin. In A. Burke \& J. Marsh (Eds.), Children's virtual play worlds: Culture, learning and participation. Oxford: Peter Lang.

Wohlwend, K. E., Vander Zanden, S., Husbye, N. E., \& Kuby, C. R. (2011). Navigating discourses in place in the world of Webkinz. Journal of Early Childhood Literacy, 11(2), 141-163. 